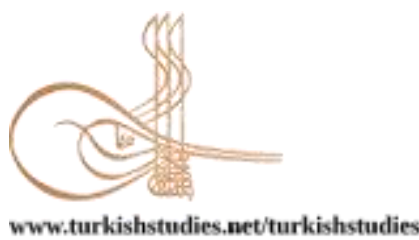

Turkish Studies

\title{
Türkiye’de Müzik Performans Kaygısı Üzerine Yapılmış Lisansüstü Çalışmaların İncelenmesi
}

\author{
An Analysis of Graduate Studies in Turkey about Musical Performance Anxiety
}

\author{
Ümit Kubilay Can* - Büşra Akbal**
}

\begin{abstract}
This research was conducted on postgraduate music performance anxiety in Turkey is aimed to study the studies. The data obtained from the research are important in terms of revealing the current status of the postgraduate studies on Music performance anxiety. The database included in the research is CHE (Council of Higher Education) National Thesis Center. Data collection in the study was terminated in April 2020. Keywords "anxiety", "performance", "music performance", "anxiety" were used to scan the study data. Among the obtained theses, those whose subject area includes music were included in the scope of the research. The obtained data were investigated and evaluated within the scope of their bibliometric properties. As a result of the research, 19 graduate theses were reached. The distribution of these theses according to years, subjects, methods and resource features has been determined. The first study has been realized in 2006. Considering the numerical distribution of the obtained theses in 3 periods, it was determined that there were 4 theses between 2006-2010, 3 between 2011-2015, and 12 between 2016-2020. In the last period, with the introduction of the Kenny Music Performance Anxiety Inventory, which was adapted to Turkish in 2013, it has been observed that the number of postgraduate studies has increased. Considering the numerical distribution of thesis types, 12 master theses and 7 doctoral theses were identified, and no research was found at the level of proficiency in art. Considering the distribution of the theses by subject areas, it was seen that there were 13 theses within the scope of the research subject regarding the relationship / effect of various variables in determining the level of anxiety, 5 theses on coping methods and strategies, 1 thesis on the factors that cause performance anxiety. In this study, which coincides with the literature results that female musicians experienced more music performance anxiety, it was shown that female researchers were more interested in music performance anxiety. It was concluded that universities with educational sciences institute music teaching programs carried out more studies on Music performance anxiety. When the subject areas of the theses are examined, it is observed that there are very few studies in the subject area of "Factors that cause performance anxiety". When looking at the methods of the theses, the relational survey model and the descriptive model; scanning, experimental, mixed and experimental models were preferred more. According to the bibliography of theses, it is striking that the use of foreign resources is higher than the use of Turkish resources. When the research results are evaluated in general, it is thought that postgraduate studies on Music Performance Anxiety are inadequate in terms of
\end{abstract}

\footnotetext{
* Doç. Dr., Kocaeli Üniversitesi, Güzel Sanatlar Fakültesi, Müzik Bölümü

Assoc. Prof. Dr., Kocaeli University, Faculty of Fine Arts, Department of Music

ORCID 0000-0001-9197-2240

kubican_gitar@hotmail.com

** Müzikolog, Kocaeli Üniversitesi, Güzel Sanatlar Fakültesi, Müzik Bölümü

Musicologist, Kocaeli University, Faculty of Fine Arts, Department of Music

ORCID 0000-0001-8419-7485

busrakbal.95@gmail.com

Cite as/ Atıf: Can, Ü. K., \& Akbal, B. (2021). Türkiye'de müzik performans kaygısı üzerine yapılmış lisansüstü çalışmaların incelenmesi. Turkish Studies, 16(1), 85-101. https://dx.doi.org/10.7827/TurkishStudies.46795

Received/Geliş: 07 October/Ekim2020

Checked by plagiarism software

Accepted/Kabul: 20 Şubat/February 2021

Published/Yayın: 25 Şubat/February 2021

CC BY-NC 4.0
} 
quantity and quality. For this reason, it is recommended to carry out new studies that reveal the factors that cause music performance anxiety and address the relevant solutions.

Structured Abstract: Anxiety is defined as fear of uncertain origin, erpart of human nature, if it gets out of control, it becomes a serious disease. Performance anxiety, which is a type of anxiety, arises when an individual performs in front of another person in areas that require performance such as public speaking, music, sports, dance.

Music is an inevitable phenomenon that takes place in all areas of human life. The essence of music is sound. The purpose of musical art is to create a sense of beauty in people, to make them think, and to create a stimulating effect on the human spirit. It also contributes to the development of creativity and responsibility skills in the individual. The human being defined as living in a cultural environment as a society, capable of thinking and speaking, able to comprehend the universe as a whole, able to change and shape as a result of his findings, is in the process of development and change that begins with birth and will continue until death. Human goes through different developmental stages and shows physiologically and psychologically different behaviors in this process.

External world is surrounded by unrestricted objects that can meet human needs. But this environment includes hazardous areas and can be both satisfying as well as scary. The human response to dangers from the external environment is fear. This feeling of fear causes anxiety in people. People may be concerned about different issues they face in daily life. Anxiety is a reaction of the human body to stress and is a natural instinct. Anxiety can be observed in many educational activities and also in performance-based areas such as music, painting, and sports. Performance concerns of musicians; Stage anxiety is expressed in terms such as performance anxiety or stress syndrome of music performers. Music performance anxiety is known in the field of psychology as a rare and relatively neglected psychological phenomenon.

This research was conducted on postgraduate music performance anxiety in Turkey is aimed to study the studies. In this direction, it has been tried to determine the contents of the postgraduate theses on music performance anxiety, to determine the number of theses given between years and how the distribution according to universities is. The results of the postgraduate studies on music performance anxiety in Turkey is expected to generate important data about its current status. The database included in the research is the Council of Higher Education (CHE) National Thesis Center. April 2020 was determined as the deadline for data collection in the study, and the scope of the study is the theses published in the National Thesis Center until this date. The keywords "anxiety", "performance", "music performance", "anxiety" was used to scan the data of the study. Among the obtained theses, those whose subject area includes music were included in the scope of the research. In the analysis of the data in the study, bibliometric analysis techniques were used. In the bibliometric analysis of the obtained theses, the criteria of "years, name information, university, subject areas, methods and bibliography" were used.

The first study has been realized in 2006. Considering the numerical distribution of the obtained theses in 3 periods, it was determined that there were 4 theses between 2006-2010, 3 between 2011-2015, and 12 between 2016-2020. It is seen that there has been a significant increase in postgraduate studies in the last period also the numerical distribution of thesis types, 12 master theses and 7 doctorate theses were determined, and no research was found at the level of proficiency in art. Considering the distribution of the theses by subject areas, it is seen that there are 13 theses within the scope of the research subject regarding the relationship / effect of various variables in determining the level of anxiety, 5 theses on coping methods and strategies, 1 thesis on the factors that cause performance anxiety and the distribution of theses by universities have been reached that Marmara University conducted 5 graduate studies in total, Gazi University 3 and İnönü University 2 graduate studies. Considering the data collection tools used to measure anxiety levels among the obtained theses, it is seen that the Kenny Music Performance Anxiety Inventory (K-MPKE) is frequently used. It has been determined that the majority of the studies were conducted by female researchers. Considering the studies in the literature on music performance anxiety, it is the common thought that female musicians experience performance anxiety more and the distribution between institutes, it was found that the theses made were more in educational sciences institutes. When the research methods of the theses are examined, it is seen that the relational survey model and descriptive model studies are preferred more than the experimental, mixed and trial models. Music performance anxiety is a situation that almost every student feels and experiences even in certain periods. When the results of the research are evaluated in general, it is thought that the postgraduate studies on Music Performance Anxiety are inadequate in terms of quantity and quality. For this reason, new 
studies with different methods and contents are recommended. Among the theses examined, it is recommended to focus on studies in this context due to the numerical lack of studies covering methods of coping with anxiety. It is recommended to include courses for performance anxiety in institutions providing music education. In this way, it can be ensured that both students' awareness of methods of coping with anxiety and that it is a subject area that can attract the attention of researchers.

Keywords: Music, performance in music, music performance anxiety, bibliography studies in music, postgraduate studies.

Öz: Bu araştırmada Türkiye’de müzik performans kaygısı üzerine yapılmış lisansüstü çalışmaların incelenmesi amaçlanmıştır. Araştırmada elde edilen veriler, Müzik performans kaygısı üzerine yapılmış lisansüstü çalışmaların güncel durumunu ortaya koyması açısından önem taşımaktadır. Araştırma kapsamına alınan veri tabanı YÖK (Yüksek Öğretim Kurumu) Ulusal Tez Merkezi’dir. Çalışmada verilerin toplanılması Nisan 2020 tarihinde sonlandırılmış̧ır. Çalışma verilerinin taranmasında "kaygı", "performans", "müzik performans", "anksiyete" anahtar kelimeleri kullanılmıştır. Elde edilen tezler arasında konu alanı müzik içerikli olanlar araştırma kapsamına dahil edilmiştir. Elde edilen veriler ise bibliyometrik özellikleri kapsamında araştırılıp, değerlendirilmiştir. Araştırma sonucunda 19 lisansüstü teze ulaş̧lmıştır. Bu tezlerin yıllara, konulara, yöntemlerine ve kaynak özelliklerine göre dağılımları tespit edilmiştir. İlk çalışmanın 2006 yılında gerçekleştirildiği görülmüştür. Elde edilen tezlerin 3 periyotta sayısal dağılımına bakıldığında, 2006-2010 yılları arasında 4 adet, 2011-2015 yılları arasında 3 adet, 2016-2020 yılları arasında ise 12 adet tezin olduğu tespit edilmiştir. Son periyota bakıldığında, 2013 yılında Türkçeye uyarlanan Kenny Müzik Performans Kaygısı Envanterinin literatüre girmesi ile birlikte lisansüstü çalışmaların sayısında artış olduğu gözlenmiştir. Tez türlerinin sayısal dağılımına bakıldığında, yüksek lisans 12 adet, doktora 7 adet tez tespit edilmiş olup, sanatta yeterlik düzeyinde bir araştırmaya rastlanılmamıştır. Konu alanlarına göre tezlerin dağılımına bakıldığında, kaygı durum düzeyinin belirlenmesinde çeşitli değişkenler ile ilişkisi/etkisine yönelik araştırma konusu kapsamında 13 tez olduğu, başa çıkma yöntem ve stratejilerine yönelik 5 tez, performans kaygısına neden olan faktörlere yönelik konusunda 1 tez olduğu görülmüştür. Kadın müzisyenlerin, müzik performans kaygısını daha fazla yaşamış olduğu yönündeki literatür sonuçları ile de örtüşen bu araştırmada, müzik performans kaygısı konusuna kadın araştırmacıların daha fazla ilgi duydukları gösterilmiştir. Eğitim bilimleri enstitüsü müzik öğretmenliği programlarına sahip olan üniversitelerin Müzik performans kaygısı konusunda daha fazla çalışma gerçekleştirdiği görülmektedir. Tezlerin konu alanlarına bakıldığında, "Performans kaygısına neden olan faktörler" konu alanında çok az sayıda çalışma olduğu göze çarpmaktadır. Tezlerin yöntemlerine bakıldığında, ilişkisel tarama modeli ve betimsel model; tarama, deneysel, karma ve deneme modellerine göre daha çok tercih edilmiştir. Tezlerin kaynakçalarına bakıldığında ise, yabancı kaynak kullanımının Türkçe kaynak kullanımımndan daha fazla olduğu göze çarpmaktadır. Araştırma sonuçları genel olarak değerlendirildiğinde, Müzik Performans Kaygısı ile ilgili lisansüstü araştırmaların sayısal ve nitelik olarak yetersiz olduğu düşünülmektedir. Bu nedenle, müzik performansı kaygısına sebep olan faktörleri ortaya koyan ve bununla ilgili çözüm yollarını ele alan yeni çalışmaların yapılması önerilmektedir.

Anahtar Kelimeler: Müzik, müzikte performans, müzik performans kaygısı, müzikte bibliyografya çalışmaları, lisansüstü çalışmalar.

\section{Giriş}

İnsan için müzik yapabilme kabiliyeti, onu diğer canlılardan ayıran bir özelliğidir. Müzik, malzemesi ses olan sanatsal bir anlatım biçimidir. Müzik ve rastgele düzensiz bir dizi sesi birbirinden ayıran şey, müziğin temel özelliklerinin birleşimi ve aralarında oluşan ilişkidir. Bu temel özellikler birleşip kendi aralarında anlamlı bir ilişki kurduklarında ölçü, ritim, tonalite, melodi ve armoni gibi üst mertebe kavramlarını oluştururlar (Levitin, 2015; Say, 2008). Müzik, insan duygu ve düşüncelerinin estetik bir anlayışla, belirli bir sistem çerçevesinde ses yoluyla dışavurumudur (Uluç, 2013: 5). Yaşamın her anında binlerce yıldan beri insanlar iç içe geçmiş bir olgudur (Say, 2008; Levitin, 2015; Uluç, 2013). İlkel insanların doğadaki sesleri taklit etmesiyle başlayan müzik yolculuğu, anne kucağından iş yerlerimize, okulumuza, radyo ve televizyonlardan günümüz konser salonlarına kadar devam eder (Say, 2008; Uluç, 2013). Müzik, insan hayatı boyunca her daim var 
olmuştur. Var olan veya var olmuş hiçbir kültür müziksiz değildir. Kazı alanlarında bulunan insan ve ilk insana ait en eski kalıntılardan bazıları müzik aletleridir. Kemikten yapılmış flütler, ağaç kökleri arasında gerilerek davul yapılan hayvan derileri. İnsan hangi sebep için bir araya gelirse gelsin, müzik de hep oradadır (Levitin, 2015).

İnsan, doğduğu andan itibaren başlayan ve ölünceye kadar süren sürekli bir gelişim ve değişim süreci içerisindedir. Fiziksel, sosyal, psikolojik ve çevresel faktörler etkisiyle evreleri şekillenir (Koç, 2004). "Toplum halinde bir kültür çevresinde yaşayan, düşünme ve konuşma yeteneği olan, evreni bütün olarak kavrayabilen, bulguları sonucunda değiştirebilen ve biçimlendirebilen canlı" olarak tanımlanır (www.tdk.gov.tr, 2020). İnsan varlı̆̆ gerçekleştirmek üzere tasarlanmış bir yapıda değildir. Bu bağlamda işlevselliği çok yönlüdür ve kendisi için en iyi olana yönelmesi işlevselliğini belirler. Ancak insanın ruhsal yaşamı bir amaçla belirlenir. İnsanın düşünebilmesi, hissedebilmesi, bir istekte bulunabilmesi, organizmanın ve dış dünyanın gerekleri ile birlikte dış çevreye bir yanıt oluşturur (Adler, 1985).

Kaynağı belirsiz korkuya "kaygı" denir. Korku ise insanın canının, malının, sevdiklerinin, inançlarının ve toplum içindeki yerinin tehdit edildiği durumlarda yaşanan bedensel belirtilerin eşlik ettiği duygusal bir tepkidir (Çankıroğlu, 2007: 64). Dış dünya insanın ihtiyaçlarını karşılayabilecek sayısız objelerle doludur. Ama bu çevre tehlikeli bölgeleri de içerir ve doyurucu olduğu kadar ürkütücüdür de. İnsanın dış çevreden gelen tehlikelere karşı olağan tepkisi korkudur. İçten ya da dıştan gelen tehdit edici güçler denetim altına alınmadığında egoya anksiyete denen duygu egemen olur (Geçtan, 1997: 64).

Anksiyete tanımlanması zor bir korku ve endişe duygusudur. Bu duyguya vücutta bir takım duyumlar eşlik edebilir. Göğüste sıkışma hissi, kalp çarpıntısı, terleme, baş ağrısı, midede boşluk duygusu ve hemen tuvalete gitme gereksiniminin doğması gibi duyumlar örnek olarak verilebilir. Huzursuzluk, dolanıp durma isteği de anksiyetenin sık görülen belirtilerindendir. Anksiyetenin ortada somut bir tehlike olmaksızın yaşanması, sık ve şiddetli bir biçimde ortaya çıkması ve kişinin olağan yaşamını etkilemeye başlaması bireyde bir anksiyete bozukluğu olduğunu düşündürür. Anksiyetenin klinik görünümleri kişiden kişiye büyük ölçüde değişir. Bazı hastalarda kas gerginliği önde gelir ve bu kişiler kas katılığından ya da spazmından, baş ağrısından ve boyun tutulmasından yakınırlar (Türkçapar, 2004: 13).

Kaygı, içten ya da dıştan insanın karşı karşıya kaldığı zorlanmaların büyüklüğü, yaşanan durumlara göre değişebilir. Kişinin karşılaştı̆̆ 1 tehdit ve zorlanmalar büyüdükçe bunlarla başa çıkabilmek için de daha büyük bir çaba, güç ve enerjiye ihtiyaç duyulur. Bunu sağlayacak imkanlardan mahrum kalındığı ya da bütün güçlerin seferber olmasına rağmen yetersiz ve başarısız kalındığında ise, ruhsal sistemin çökmesi ve normal işlevlerini yerine getirememesi durumu ortaya çıkar (Hökelekli, 2009: 205).

Spielberger'e (1972) göre ilk defa Cattel ve Scheirer'in $(1958 ; 1961)$ çalışmalarında faktör analizi ile belirlenen ve "durumluk kaygı", "sürekli kaygı" olarak isimlendirilen iki tür kayg1 tanımlanmaktadır (Akt., Büyüköztürk,1997). Durumluk kaygı, öznel gerilim ve korku kavramları ile tanımlanmaktadır. Doğal koşulların dışında, belirli durumlarda ve bireyin kendini tehdit altında hissettiği koşullarda ortaya çıkar. Tehdit unsuru ortadan kalkınca kaygı da yok olur. Sürekli kayg1 ise, göreli olarak bireyde var olan kaygı eğilimini göstermekte olup, çevresel koşullardan bağımsız olarak bireyin huzursuzluk hissetmesi, kaygı ve endişe duyması, yoğun heyecansal reaksiyonlarda bulunma eğilimidir (Öztürk, 2008).

Kayg1, tehlikeyi haber veren, doğal ve gerekli bir sinyaldir ve vücutla zihnin bir meydan okumaya ya da tehdide, en kısa zamanda hazır olmasını sağlar. Kalp daha hızlı atmaya başlar, soluk alıp verişiniz hızlanır, bu da kaslara daha fazla oksijen gitmesini sağlar. Böylece bir mücadele durumunda daha iyi dövüşebilir, kaçmanız gerekirse daha hızlı koşmaya başlarsınız (Anonim, 2008: 2). Kaygı, kişinin korku veya tehdit edici bir duruma karşı vermiş olduğu ruhsal ve bedensel bir 
tepkidir. Bu tepkiyi zaman zaman her insan yaşar. Bir kaza atlatıldığında, sınav öncesinde veya topluluk önünde bir konuşma yaparken olduğu gibi (Pişkin, 1991). Kaygı, pek çok eğitim öğretim faaliyetleri içinde ve aynı zamanda müzik, resim, spor gibi performansa dayalı alanlarda da gözlemlenebilir. Müzisyenlerin performans kaygıları; sahne kaygısı, performans kaygısı ya da müzik performansçılarının stres sendromu gibi kavramlar ile tanımlanır (Fehm ve Schmidt, 2006).

Performans kavramı, dilimize İngilizce "performance" kelimesinden geçmiştir. İcra etmek, başarı ve başarım gibi anlamları bulunmaktadır. Bir şeyi başarmak, zamanla olgunlaştırmak ve çaba sarf etmek gibi eylemleri karşılar (www.tdk.gov.tr, 2020). Amaçlı ve planlı faaliyetler sonucunda ulaşılanı nicel ve nitel olarak belirleyen bir kavram olup mutlak ya da göreceli olarak açıklanabilir (Kubal1, 1999). Performans "bir fiziksel aktivite sırasında, o fiziksel aktivitenin gerektirdiği fizyolojik, biyomekanik ve psikolojik verimdir." Bu verimi ortaya koyabilme düzeyi de performans düzeyi hakkında bilgi verir (Akt., Başaran, 2008). Performansın hazırlanması ve sunulma süreci bilişsel, duyusal ve devinişsel becerilerin kazanılmasıyla mümkün olacağından psikoloji alanı ile doğrudan ilgilidir (Sarıkaya, 2018: 8). Kaygı herhangi bir yerde ve durumda ortaya çıkabilir. Bu durumlardan bir tanesi performans sergileme durumunda kalındığı andır. Performans kaygısının oluşumunda pek çok faktör etken olmaktadır. Performans sergileyen kişi tarafindan seyirci bir tehdit durumu oluşturabilir ve performansı olumsuz yönde etkilenebilir (Dalkıran vd., 2014). Performans kaygısı, bireyin bir başkasının önünde performans sergilemesi sonucu; toplum önünde konuşma, müzik, spor, dans gibi alanlarda ortaya çıkmaktadır. Tanımadık insanlarla karşılaştığı ya da başkalarının gözü üzerinde olabileceği, bir ya da birden çok toplumsal ya da bir eylemi gerçekleştirdiği durumdan korku duyması performans kaygısını oluşturur.

Kaygının yüksek düzeyde olması performansı olumsuz yönde etkileyebilmektedir. Buna nazaran kaygının düşük olması da motivasyon eksikliğini gösterir. Performans kaygısının belirtileri fizyolojik, bilişsel ve davranışsal olabilir. Fizyolojik belirtiler arasında; nabız artışı, nefes alıp verişinin hızlanması, nefes darlığı ağız kuruluğu, terleme ile bilişsel belirtiler arasında özgüven kaybı, konsantrasyon kaybı, hafıza hataları gibi durumlar ortaya çıkar. Davranışsal belirltiler arasında ise, titreme, güçsüzlük, sesin titremesi, ruhsuz yüz ifadesi ve performans hataları oluşabilir (Özevin Tokinan, 2013; Fehm ve Schmidt, 2006).

Müzik performans kaygısı, müzisyenlerin performans gösterme durumunda hissettikleri kayg1 olarak tanımlanır (Gencer, 2019). Performans kaygısı birçok müzisyenin performans potansiyelini gösterme konusunda engel taşıan bir problemdir (LeBlan vd., 2016). Müzik performans kaygis1, konsantrasyon güçlüğü, performansa yönelik olumsuz düşünceler, beklentileri karşılayamama endişesi, hata yapmaktan korkma gibi süreçler ile oluşur. Müzisyenlerin performans kaygıları; sahne kaygısı, performans kaygısı ya da müzik performansçılarının stres sendromu gibi kavramlar ile tanımlanır (Fehm ve Schmidt, 2006).

Kaygı, tecrübeye ve yaşa bakılmaksızın profesyonel ve amatör yaşamda ortaya çıkabilir. Özellikle henüz kariyerlerinin başlarında olan müzisyenleri sakatlanmaya hatta çalgısını çalamayacak duruma getirecek kadar ciddi problemlere yol açabilir. Bu problemler, müzisyenlerin bireysel ya da toplu müzik yaparken stres ve baskı altında hissettikleri andan itibaren performans kaygısı duymalarına neden olmakta, sonucunda ise bilişsel ve psikolojik uyaranları harekete geçirebilmektedir (Baydağ ve Bolat Başoğlu, 2018; Çırakoğlu, 2013; Fehm ve Schmidt, 2006; Kenny, 2006). Performans kaygısında yetersiz hazırlanmanın ya da algılanan yeterliğin önemli bir etken olduğu vurgulanmaktadır (Kenny, 2006). Bazı müzisyenlerin, sahneye çıkmadıkça anksiyete seviyeleri artar. Profesyonel müzisyenler için en önemli dört stres kaynă̆ $1, \% 45$ düzensiz çalışma saatleri, \%43 aileden ayrı kalma, \%43 provaların monoton gelişmesi, $\% 42$ de seyahatleridir (Gidergi, 2012:139).

İcracının yaşadığı performans kaygısı, duygusal, zihinsel ve fiziksel bir durum olduğu için her an bir hata olacak endişesiyle gergin ve tedirgin bir performansın oluşmasına sebep olur ve 
izleyiciyle olan karşılıklı aktarım bu nedenle zedelenip performans boyunca süren ve bir türlü kırılamayan bir kısır döngüye dönüşebilir. Müzisyen, çoğunlukla bir sonraki performans için artık günler öncesinden olumsuz düşüncelere kapılır ve bu döngü giderek sertleşebilir (Kabakçı, 2016). Performans kaygısı bazen yeteri kadar hazırlık yapamama gibi somut bir tepki olabilirken genellikle algılanan yeterlik, kaygıyı belirleyen temel bir faktör değildir. Kaygı yaşayan öğrencinin bazen kendine güvensizlik gibi kişilik özellikleri, bazen negatif düşünmeye kapılma durumu ya da çevresel uyarıcılara aşırı duyarlık, uyarıcıları tehdit edici olarak algılama gibi bilişsel özellikleri kaygı durumunu ortaya çıkarabilmektedir (Yöndem, 2012). Müzik performans kaygısına tıpkı diğer kaygılar gibi, bilişsel, psikolojik ve kişisel faktörler neden olmaktadır. Geçmiş deneyimler, izleyicilerin potansiyeli, mükemmeliyetçilik anlayışı, beğenilme kaygısı gibi sebeplerle ortaya çıabilir (Cemali, 2017).

\section{Problem}

Müzik performans kaygısı her yaş ve gruptan (amatör/profesyonel) olan müzisyenlerin yaşayabileceği olağan bir kaygı durumudur. Hata yapma korkusu, performans üzerine düşünmesi, konsantrasyon sorunları gibi pek çok etkenler sonucu ortaya çıkabilmekte ve müzik performansını olumsuz yönde etkileyebilmektedir. Bu araştırmada Türkiye'de müzik performans kaygısı üzerine yapılmış lisansüstü çalışmaların içerik analizinin yapılması amaçlanmaktadır. Bu doğrultuda müzik performans kaygısı üzerine yapılmış lisansüstü tezlerin içeriklerinin ne olduğu, yıllar arasında verilen tez sayılarının saptanabilmesi ve üniversitelere göre dağılımının nasıl olduğu bu araştırmanın problemini oluşturmaktadır.

\section{Amaç}

Bu araştırma, Türkiye'de müzik performans kaygısı üzerine yapılmış lisansüstü çalışmaların bibliyometrik özellikleri kapsamında özelliklerini ortaya koymayı amaçlamaktadır. Bu bağlamda aşağıdaki sorulara yanıt aranacaktır:

1. Tezlerin yıllara göre dağılımı ile ilgili bulgular nasıldır?

2. Türkiye'de müzik performans kaygısı üzerine yazılan tezlerin künye (tez başlığı, yazarın ismi, üniversite-enstitü, lisansüstü düzeyi ve yıllara) bilgileri ile ilgili bulgular nasıldır?

3. Tezlerin üniversitelere göre dağılımı ile ilgili bulgular nasıldır?

4. Türkiye'de müzik performans kaygısı üzerine yazılan tezlerin içerdiği konulara göre sayısal dağılımı ile ilgili bulgular nasıldır?

5. Türkiye'de müzik performans kaygısı üzerine yazılan tezlerin yöntemlerine (Araştırma modeli, örneklem niteliği ve veri toplama araçları) ile ilgili bulgular nasıldır?

6. Türkiye'de müzik performans kaygısı üzerine yazılan tezlerin kaynak özelliklerine göre dağılımı nasıldır?

$\mathrm{Bu}$ araştırma müzik performans kaygısı konusunda gerçekleştirilen lisansüstü tezlerin güncel durumunu ortaya koyması açısından önem taşımaktadır. Çalışmada tezlerin konu içerikleri ve yöntemleri hakkında elde edilen veriler, müzik performans kaygısı konusunda var olan eksiklerin tespit edilmesinde araştırmacılara 1şık tutacaktır. Türkiye'de 2000-Nisan 2020 yılları arasında müzik performans kaygısı üzerine yapılmış lisansüstü tezler bu araştırmanın sınırlılıkları içerisindedir. Araştırma kapsamına alınan veri tabanı YÖK Ulusal Tez Merkezi’dir. Tarama sonuçlarında elde edilmiş "Tez adı" başlı̆̆ında kaygı, performans, müzik performans, anksiyete kelimelerinin taratılıp, "Konu" başlığında müzik kelimesi kullanılarak elde edilen lisansüstü tezler ile sınırlandırılmıştır. 


\section{Yöntem}

Bibliyometri, istatiksel ve matematiksel yöntemlerin kitaplar ve diğer iletişim ortamlarına uygulanması olarak tanımlanmaktadır (Pritchard, 1969). "Bibliyometrik araştırmalar, bilim dallarının kendi alanlarındaki yayın yeterliliğini; yayın sayısı, yayın niteliği, yayın yapılan dergilerin ait olduğu indekslerin seçimi gibi ölçütler 1şı̆̆ında değerlendirerek, geleceğe yönelik bilim politikalarının oluşturulmasına yardımcı olmaktadır" (Alkan, 2014: 42). Buradan hareketle çalışmada, müzik performans kaygısı üzerine gerçekleştirilen akademik tezlerin bibliyometrik özellikleri kapsamında araştırılıp, değerlendirilmesi istenmiştir.

Çalışmanın ilk aşamasında ulusal tez merkezi veri tabanı "kaygı, performans, müzik performans ve anksiyete" anahtar kelimeleri ile taratılmış ve müzik performans kaygısı üzerine yapılmış 20 lisans üstü tez elde edilmiştir. İkinci aşamasında, elde edilen tezlerin bir kısmı müzik alanı dışındaki bilim dallarında gerçekleştirildiği için bu kapsamlı 1 tez, çalışmadan çıkarılmış ve 12'si yüksek lisans 7'si doktora olmak üzere toplamda 19 lisansüstü tez çalışmaya dahil edilmiştir.

Bibliyometri aynı zamanda, akademik yayınların çeşitli unsurlarının (yazar, konu, yıl, sayfa sayısı, yapılan atıflar vb.) sayısal analizler ve istatistikler yardımıyla incelenmesi ile ilgilenmektedir. Bibliyometrik analizler, tanımlayıcı nitelikte (belirli bir yılda yayımlanan makale sayısının belirlenmesi) olabileceği gibi, değerlendirici nitelikte de (bir makalenin kendisinden sonra gelen araştırmaları ne şekilde etkilediğini ortaya koymak için atıf analizi yapılması) olabilirler (McBurney ve Novak, 2002: 108).

Çalışmada verilerin analizinde, bibliyometrik analiz teknikleri kullanılmıştır. Elde edilen tezlerin bibliyometrik analizinde "yılları, künye bilgileri, üniversite, konu alanları, yöntemleri ve kaynakçaları" kriterlerinden yararlanılmıştır. Her bir analiz öncesinde veriler detaylı şekilde incelenmiştir. Veriler analiz edilerek çözümlenmiş, değerleri tablo haline getirilip yorumlanmıştır.

\section{Bulgular}

\section{Tezlerin yıllara göre dağılımı ile ilgili bulgular nasıldır?}

Tablo 1: Tezlerin Yıllara Göre Dağılımı

\begin{tabular}{lcccc}
\hline Tez Türü & $2006-2010$ & $2011-2015$ & $2016-2020$ & Toplam \\
\hline YüksekL. & 4 & 1 & 7 & 12 \\
Doktora & - & 2 & 5 & 7 \\
\hline Toplam & 4 & 3 & 12 & 19 \\
\hline
\end{tabular}

Tablo 1 incelendiğinde, ülkemizde müzik performans kaygısı üzerine 2006 senesi öncesinde yapılmış lisansüstü çalışması bulunmadığı, ilk yapılan lisansüstü tezlerinin 2006 yılı itibari ile başladığı görülmektedir. 2020 yılına kadar 3 periyotta müzik performans kaygısı üzerine gerçekleştirilen tezlerin sayısal olarak dağılımına bakıldığında 2006-2010 yılları arasında 4 tezin yüksek lisans tezi olduğu, 2011-2015 y1lları arasında 2 doktora, 2016-2020 yılları arasında da 7 yüksek lisans ve 5 doktora çalışması olduğu görülmektedir. Bu periyotlar neticesinde en çok 20152020 yılları arasında çalışma sayısının fazla olduğu, 2010-2014 yılları arasında da en az olduğu görülmektedir. 2006-2010 yılları arasında yalnızca yüksek lisans çalışması olmakla beraber bir sonraki periyotta yalnızca doktora çalışmalarının olduğu dikkat çekmektedir. Toplamda yüksek lisans ve doktora seviyesindeki çalışmaların sayısal olarak birbirine yakın olduğu görülmektedir. 
Türkiye'de müzik performans kaygısı üzerine yazılan tezlerin künye (tez başlı̆̆ı, yazarın ismi, üniversite-enstitü, lisansüstü düzeyi ve yıllara) bilgileri ile ilgili bulgular nasıldır?

Tablo 2: Tezlerin Künye Bilgilerine Göre Dağılımı

\begin{tabular}{lllll}
\hline $\begin{array}{l}\text { Tez } \\
\text { kodu }\end{array}$ & Tez Başlığ & Tez & Üniversite/Enstitü & Yıll \\
\hline T.1. & Müzik öğretmeni yetiştiren & Yüksek & Uludağ \\
& $\begin{array}{l}\text { kurumlarda solo konserlere katıllan şan } \\
\text { öğrencilerinin seslendirme }\end{array}$ & Lisans & $\begin{array}{l}\text { Üniversitesi/Sosyal } \\
\text { Bil.Enstitüsü }\end{array}$ & 2006 \\
& & &
\end{tabular}

kaygılarının değerlendirilmes

T.2. Gazi eğitim fakültesi müzik

öğretmenliği programı piyano

Yüksek Gazi

2007

öğrencilerinin vize ile final süreci arasındaki kaygı düzeylerinin başarı düzeylerine göre incelenmesi

T.3. Piyanistler örneğinde müzisyenlere özgü performans anksiyetesi

Lisans

Üniversitesi/Eğitim

Bil.Enstitüsü

Yüksek Dokuz Eylül

Lisans Üniversitesi/Güzel

Sanatlar Ensitüsü

T.4. Güzel sanatlar eğitimi bölümü müzik

Yüksek

İnönü

öğretmenliği programında okuyan

öğrencilerin mesleki heyecan ve

Lisans

Üniversitesi/Sosyal

Bil.Enstitüsü

T.5. Müzik eğitimi anabilim dalı öğrencilerinin müzikte performans kaygı düzeylerine video geri bildirim yönteminin etkisi

T.6. Ergenlerde performans kaygisinı yordayan değişkenlerin modellenmesi ve buna yönelik psiko-eğitim programının işlevselliği

T.7 Solist sanatçıların sahne performanslarına ilişkin kaygı durumlarının müzikal performansa etkisi

T.8. Müzik öğretmeni adaylarının müzik performansı kaygı düzeyleri ve akademik motivasyon düzeylerinin incelenmesi

T.9. Flüt öğretiminde birlikte çalma öğrenme biçiminin performans kaygısı ve motivasyon düzeyine etkisi

Doktora Gazi

Üniversitesi/Eğitim

Bil.Enstitüsü

Doktora Sakarya

Üniversitesi/Eğitim

Bil.Enstitüsü

Yüksek Erciyes

Lisans Üniversitesi/Güzel Sanatlar Enstitüsü

Yüksek Marmara

Lisans

Üniversitesi/Eğitim

Bil.Enstitüsü

Doktora İnönü

Üniversitesi/Eğitim

Bil.Enstitüsü

T.10. Ergenlerin müzikal performans kaygis1 ile ailelerin beklentileri arasındaki ilişski

Yüksek

Marmara

Lisans Üniversitesi/Eğitim

Bil.Enstitüsü

T.11. Müzisyenlerin performans kaygisıyla başa çıkmada kullandıkları bilişsel stratejileri

Doktora

Marmara

Üniversitesi/Eğitim

Bil.Enstitüsü

T.12. Müzik bölümü lisans öğrencilerinde performans kaygisina neden olan faktörlerin belirlenmesi

Yüksek

Hacettepe

Lisans Üniversitesi/Sağl1k

Bil.Enstitüsü

T.13. Konservatuvarda ortaokul ve lise düzeyinde öğrenim gören müzik

Doktora Afyon Kocatepe öğrencilerinin müzik performans kaygı Üniversitesi/Eğitim Bil. düzeyleri ile duygusal zeka

Enstitüsü 
düzeylerinin çeşitli değişkenlere göre incelenmesi

T.14. Müzik öğretmeni adaylarının

T.15. Mesleki müzik eğitimi veren

T.17. Müzik öğretmenlerinin müzik mükemmeliyetçilik ve öz yeterlik inançlarına göre müzik performans kaygılarının yordanması kurumlarda performans kaygısı ve öz yeterlik algısının çalgı başarısına etkisi

T.16. Müzisyenlerde performans kaygısı, trompet performansına etkileri ve başa çıkma yöntemleri performans kaygılarının ve iş doyumlarının çeşitli değişkenler açısından incelenmesi

T.18. Çalg1 eğitiminde öz düzenlemeli ögrenme ile performans kaysı düzeyi arasındaki ilişkiler

\author{
Doktora Necmettin Erbakan \\ Üniversitesi/Eğitim \\ Bil.Enstitüsü
}
Yüksek Marmara
Lisans
Üniversitesi/Eğitim
Bilimleri Enstitüsü

Yüksek Anadolu

Lisans Üniversitesi/Güzel

Sanatlar Enstitüsü

Yüksek Marmara

Lisans Üniversitesi/Eğitim

Bil.Enstitüsü

Yüksek Akdeniz

Lisans Üniversitesi/Güzel

Sanatlar Enstitüsü

Doktora Gazi

Üniversitesi/Eğitim

Bil.Enstitüsü
2018

2018 egzersizlerinin öğrencilerin sınav kaygıları ve performans başarılarına etkisi

Tablo 2'de tezlerin başlık ve künye bilgileri yer almaktadır. Müzik performans kaygısı üzerine sosyal bilimler, eğitim, güzel sanatlar, sağlık bilimleri ve sosyal bilimler enstitüsü kapsamında yapılmış lisansüstü çalışmalar olmakla beraber çalışmaların eğitim bilimleri enstitüsünde daha fazla olduğu görülmektedir. 2006-2020 yılları arasında toplamda 19 adet lisansüstü çalışması yapılmıştır. Çalışmaların çoğunluğu kadın araştırmacılar tarafından yapıılmıştır.

\section{Tezlerin üniversitelere göre sayısal dağılımı ile ilgili bulgular nasıldır?}

Tablo 3: Tez Türlerinin Üniversitelere Göre Dağılımı

\begin{tabular}{lccc}
\hline Üniversite & Y.L. & Dr. & Toplam \\
\hline Marmara Üniversitesi & 4 & 1 & 5 \\
Gazi Üniversitesi & 1 & 2 & 3 \\
İnönü Üniversitesi & 1 & 1 & 2 \\
Afyon Kocatepe Üniversitesi & - & 1 & 1 \\
Dokuz Eylül Üniversitesi & 1 & - & 1 \\
Erciyes Üniversitesi & 1 & - & 1 \\
Akdeniz Üniversitesi & 1 & - & 1 \\
Hacettepe Üniversitesi & 1 & - & 1 \\
Anadolu Üniversitesi & 1 & - & 1 \\
Necmettin Erbakan Üniversitesi & - & 1 & 1 \\
Sakarya Üniversitesi. & - & 1 & 1 \\
Uludağ Üniversitesi & 1 & - & 1 \\
\hline Toplam & 12 & 7 & 19 \\
\hline
\end{tabular}

Tablo 3'e bakıldığında müzik performans kaygısı üzerine yapılmış toplamda 12 yüksek lisans ve 7 doktora tezi bulunmaktadır. Marmara Üniversitesi'nin toplamda 5 lisansüstü çalışma, ardından Gazi Üniversitesi'nin 3 ve İnönü Üniversitesi'nin 2 adet lisansüstü çalışması verdiği görülmektedir. Diğer üniversiteler toplamda 1'er yüksek lisans ya da doktora seviyesinde çalışmalar vermiştir. 


\section{Türkiye'de müzik performans kaygısı üzerine yazılan tezlerin içerdiği konulara göre dağılımı ile ilgili bulgular nasıldır?}

Tablo 4: Yüksek Lisans Tezlerinin Konulara Göre Dağılımları

\begin{tabular}{llccc}
\hline Konu & & Tez Sayısı (f) & $\%$ & Toplam \% \\
\hline Kaygı durum düzeyinin belirlenmesinde & Yüksek Lisans & 10 & 52.63 & 68.42 \\
çeşitli değişkenlerin ilişkisi/etkisine & Doktora & 3 & 15.79 & \\
yönelik & & & & \\
Başa çıkma yöntem ve stratejilere & Yüksek Lisans & 1 & 5.26 & 26.31 \\
yönelik & Doktora & 4 & 21.05 & \\
Performans kaygısına neden olan & Yüksek Lisans & 1 & 5.26 & 5.26 \\
faktörlere yönelik & Doktora & - & - & \\
\hline Toplam & & 19 & 100.00 & 100.00 \\
\hline
\end{tabular}

Tablo 4'e bakıldığında 3 farklı konu alanı yer almaktadır. Bu konu alanlarına göre yapılan tezlere bakıldığında kaygı durum düzeyinin belirlenmesinde çeşitli değişkenlerin ilişkisi/etkisine yönelik araştırma konusu kapsamında 13 (\%69.26) tez olduğu, başa çıkma yöntem ve stratejilerine yönelik 5 (\%26.31) tez, performans kaygısına neden olan faktörlere yönelik konusunda 1 (\%5.26) tez olduğu görülmektedir. Kayg1 durum düzeyinin belirlenmesinde çeşitli değişkenlerin ilișkisi/etkisine yönelik tezlerde yüksek lisans çalışmalarının sayısal olarak daha fazla olduğu saptanmıştır. Başa çıkma yöntem ve stratejilerine yönelik konusunda doktora tezlerinin sayısı daha fazladır. Performans kaygısına neden olan faktörlere yönelik doktora çalışması yapılmamıştır.

Türkiye'de müzik performans kaygısı üzerine yazılan tezlerin yöntemleri (araştırma modeli, örneklem niteliği ve veri toplama araçları) ile ilgili bulgular nasıldır?

Tablo 5: Türkiye'de Müzik Performans Kaygısı Üzerine Yazılan Tezlerin Yöntemlerine (araştırma modeli, örneklem niteliği ve veri toplama araçları) Göre Dağılımı

\begin{tabular}{|c|c|c|c|c|c|}
\hline $\begin{array}{l}\text { Tez } \\
\text { no }\end{array}$ & $\begin{array}{l}\text { Araştırma } \\
\text { modeli }\end{array}$ & $\begin{array}{c}\text { Örneklem/Çalışma } \\
\text { niteliği }\end{array}$ & $\begin{array}{c}\text { Örneklem/ } \\
\text { Çalışma } \\
\text { Grubu } \\
\text { Sayısı }\end{array}$ & Veri toplama araçları & $\begin{array}{c}\text { Veri } \\
\text { çözümleme }\end{array}$ \\
\hline T.1. & $\begin{array}{l}\text { Betimsel } \\
\text { Model }\end{array}$ & $\begin{array}{l}\text { Lisans Düzeyi Müzik } \\
\text { Programı/Solo konsere } \\
\text { katılan öğrenciler }\end{array}$ & 55 & Anket Formu & $\begin{array}{c}\text { Betimsel } \\
\text { Analiz }\end{array}$ \\
\hline T.2. & $\begin{array}{l}\text { Betimsel } \\
\text { Model }\end{array}$ & $\begin{array}{l}\text { Lisans Düzeyi Müzik } \\
\text { Programi/Piyano eğitimi } \\
\text { alan öğrenciler }\end{array}$ & 150 & Anket Formu & $\begin{array}{l}\text { Betimsel } \\
\text { Analiz }\end{array}$ \\
\hline T.3. & $\begin{array}{l}\text { Deneysel } \\
\text { Model }\end{array}$ & $\begin{array}{l}\text { Lisans Düzeyi Müzik } \\
\text { Programı/Müzik } \\
\text { öğrencileri }\end{array}$ & 109 & Kaygı Ölçeği & $\begin{array}{l}\text { Betimsel } \\
\text { İstatistik }\end{array}$ \\
\hline T.4. & $\begin{array}{l}\text { Betimsel } \\
\text { Model }\end{array}$ & $\begin{array}{l}\text { Lisans Düzeyi Müzik } \\
\text { Programı/Müzik } \\
\text { öğretmen adayları }\end{array}$ & 120 & Tarama/Anket Formu & $\begin{array}{c}\text { Betimsel } \\
\text { Analiz }\end{array}$ \\
\hline T.5. & $\begin{array}{l}\text { Deneme } \\
\text { Modeli }\end{array}$ & $\begin{array}{l}\text { Lisans Düzeyi Müik } \\
\text { Programı/Müzik } \\
\text { öğretmen adayları }\end{array}$ & 52 & $\begin{array}{c}\text { Kaygı Ölçeği/Demografik } \\
\text { Bilgi Anketi }\end{array}$ & $\begin{array}{l}\text { Non } \\
\text { parametrik } \\
\text { Analiz }\end{array}$ \\
\hline T.6. & $\begin{array}{l}\text { Betimsel } \\
\text { Model/Deneys } \\
\text { el Model }\end{array}$ & $\begin{array}{l}\text { Ortaöğretim Müzik } \\
\text { Bölümü/ Lise } \\
\text { Öğrencileri }\end{array}$ & 411 & Kaygı Ölçeği & $\begin{array}{l}\text { Betimsel } \\
\text { İstatistik }\end{array}$ \\
\hline T.7. & $\begin{array}{l}\text { Betimsel } \\
\text { Model }\end{array}$ & $\begin{array}{l}\text { Müzisyenler/Profesyonel } \\
\text { müzisyenler }\end{array}$ & 10 & Görüşme Formu & $\begin{array}{l}\text { Betimsel } \\
\text { Analiz }\end{array}$ \\
\hline Т.8. & $\begin{array}{l}\text { İlişkisel } \\
\text { Tarama } \\
\text { Modeli }\end{array}$ & $\begin{array}{l}\text { Lisans Düzeyi Müzik } \\
\text { Programı/Müzik } \\
\text { öğretmen adayları }\end{array}$ & 241 & $\begin{array}{c}\text { Demografik Bilgi } \\
\text { Formu/Kayg1 Ölçeği }\end{array}$ & $\begin{array}{l}\text { Betimsel } \\
\text { İstatistik }\end{array}$ \\
\hline
\end{tabular}




\begin{tabular}{|c|c|c|c|c|c|}
\hline T.9. & Karma Model & $\begin{array}{l}\text { Lisans Düzeyi Müzik } \\
\text { Programı/Müzik } \\
\text { öğretmen adayları }\end{array}$ & 14 & $\begin{array}{c}\text { Kayg1 Ölçeği/Çalg1 } \\
\text { Güdüleme Ölçeği/Görüşme } \\
\text { formu }\end{array}$ & $\begin{array}{l}\text { Betimsel } \\
\text { İstatistik }\end{array}$ \\
\hline T.10. & $\begin{array}{l}\text { İlişkisel } \\
\text { Tarama } \\
\text { Modeli }\end{array}$ & $\begin{array}{c}\text { Ortaöğretim Müzik } \\
\text { Bölümü/Lise Öğrencileri }\end{array}$ & 180 & $\begin{array}{c}\text { Mükemmeliyetçilik } \\
\text { Ölçeği/Kaygı Ölçeği/Kişisel } \\
\text { Bilgi Formu }\end{array}$ & $\begin{array}{l}\text { Betimsel } \\
\text { Analiz }\end{array}$ \\
\hline T.11. & $\begin{array}{l}\text { İlişkisel } \\
\text { Tarama } \\
\text { Modeli }\end{array}$ & $\begin{array}{l}\text { Müzik Eğitimi Veren ve } \\
\text { Sanat Etkinlikleri } \\
\text { Düzenleyen } \\
\text { Kurumlar/Bu kurumlarda } \\
\text { eğitim alan ve çalışanlar }\end{array}$ & 346 & $\begin{array}{l}\text { Anket Formu/Kişisel Bilgi } \\
\text { Formu/Kaygı } \\
\text { Ölçeği/Görüşme Formu }\end{array}$ & $\begin{array}{l}\text { Betimsel } \\
\text { İstatistik }\end{array}$ \\
\hline T.12. & $\begin{array}{l}\text { Betimsel } \\
\text { Model }\end{array}$ & $\begin{array}{l}\text { Lisans Düzeyi Müzik } \\
\text { Programı/K-MPKE } 105 \\
\text { üstü alan bireyler }\end{array}$ & 26 & Görüşme Formu & $\begin{array}{l}\text { Betimsel } \\
\text { Analiz }\end{array}$ \\
\hline T.13. & $\begin{array}{l}\text { İlişkisel } \\
\text { Tarama } \\
\text { Modeli }\end{array}$ & $\begin{array}{c}\text { Ortaokul ve Lise Düzeyi } \\
\text { Müzik Programı/Müzik } \\
\text { ögrencileri }\end{array}$ & 840 & $\begin{array}{c}\text { Duygusal Zeka } \\
\text { Ölçeği/Kayg1 Ölçeği }\end{array}$ & $\begin{array}{l}\text { Betimsel } \\
\text { Analiz }\end{array}$ \\
\hline Т.14. & $\begin{array}{l}\text { İlişkisel } \\
\text { Tarama } \\
\text { Modeli }\end{array}$ & $\begin{array}{l}\text { Lisans Düzeyi Müzik } \\
\text { Programı/Müzik } \\
\text { ögretmen adayları }\end{array}$ & 541 & $\begin{array}{l}\text { Kişisel Bilgi Formu/Kayg1 } \\
\text { Ölçeği/Mükemmeliyetçilik } \\
\text { ölçeği/Çalg1 Performansı Öz } \\
\text { yeterlik İnancı Ölçeği }\end{array}$ & $\begin{array}{l}\text { Betimsel } \\
\text { Analiz }\end{array}$ \\
\hline Т.15. & $\begin{array}{l}\text { Tarama } \\
\text { Modeli }\end{array}$ & $\begin{array}{l}\text { Lisans Düzeyi Müzik } \\
\text { Programı/Müzik } \\
\text { öğretmen adayları }\end{array}$ & 242 & $\begin{array}{l}\text { Kişisel Bilgi Formu/Kayg1 } \\
\text { Ölçeği/ Çalg1 Performans1 } \\
\text { Özyeterlik İnanc1 Ölçeği }\end{array}$ & $\begin{array}{l}\text { Betimsel } \\
\text { Analiz }\end{array}$ \\
\hline T.16. & $\begin{array}{l}\text { Tarama } \\
\text { Modeli }\end{array}$ & - & - & - & $\begin{array}{l}\text { Betimsel } \\
\text { Analiz }\end{array}$ \\
\hline T.17. & $\begin{array}{l}\text { İlişkisel } \\
\text { Tarama } \\
\text { Modeli }\end{array}$ & $\begin{array}{l}\text { M.E.B.'e Bağli } \\
\text { Kurumlar/Müzik } \\
\text { öğretmenleri }\end{array}$ & 101 & $\begin{array}{l}\text { Kişisel Bilgi Formu/Kayg } \\
\text { Ölçeği/ İş Doyum Ölçeği }\end{array}$ & $\begin{array}{l}\text { Betimsel } \\
\text { Analiz }\end{array}$ \\
\hline T.18. & $\begin{array}{l}\text { Tarama } \\
\text { Modeli }\end{array}$ & $\begin{array}{l}\text { Lisans Düzeyi Müzik } \\
\text { Programı/Müzik } \\
\text { öğrencileri }\end{array}$ & 190 & $\begin{array}{c}\text { Kişisel Bilgi Formu/Kayg1 } \\
\text { Ölçeği/ Çalgi Performans1 } \\
\text { Özyeterlik İnancı Ölcceği } \\
\text { /Müzik yeteneğine ilişkin } \\
\text { özyeterlik ölçeği }\end{array}$ & $\begin{array}{l}\text { Betimsel } \\
\text { İstatistik }\end{array}$ \\
\hline T.19. & $\begin{array}{l}\text { Deneysel } \\
\text { Model }\end{array}$ & $\begin{array}{l}\text { Lisans Düzeyi Müzik } \\
\text { Programı/Flüt öğrencileri }\end{array}$ & 10 & $\begin{array}{l}\text { Kayg } 1 \text { Ölçeği/Performans } \\
\text { Değerlerndirme Formu }\end{array}$ & $\begin{array}{c}\text { Non- } \\
\text { parametrik } \\
\text { Analiz/ } \\
\text { Betimsel } \\
\text { Analiz }\end{array}$ \\
\hline
\end{tabular}

Tablo 5 incelendiğinde yüksek lisans ve doktora tezlerinin içerikleri incelenmiş araştırma modeli, örneklem niteliği, örneklem sayısı, veri toplama araçları ve veri analizleri tespit edilmiştir.

Araştırma modellerinden en çok betimsel model ve ilişkisel tarama modelinin kullanıldığı görülmektedir. En az karma modelde çalışma yapılmıştır.

Tezlerin 12'sinde örneklem grubu olarak lisans düzeyi müzik eğitimi alan öğrencilerden oluştuğu görülmekle birlikte 3 tezin ortaokul ve lise öğrencisi örneklem grubundan oluşmaktadır. Müzik öğretmenleri, profesyonel müzisyenler, sanat kurumlarında eğitim gören ve çalışanlardan oluşan örneklem grubunda ise 1'er çalışma yapılmıştır. Örneklem grubu çalışma sayılarında en çok 840 kişiyle gerçekleştirilen ortaokul ve lise düzeyi müzik öğrencilerinden oluşmaktadır. En az 10 örneklem grubu ile çalışmalar yapılmıştır.

Veri toplama araçlarından kaygı ölçeklerinin en çok kullanılan araç olduğu görülmektedir. Kaygı ölçeklerinin ardından kişisel bilgi formu, anket ve görüşme formu kullanılmıştır. Tezlerin veri 
çözümlemesine bakıldığında araştırmaların çoğunluğu betimsel analiz çalışmalarından oluşmaktadır. En az sayıda olanlar ise non-parametrik çalışmalardır.

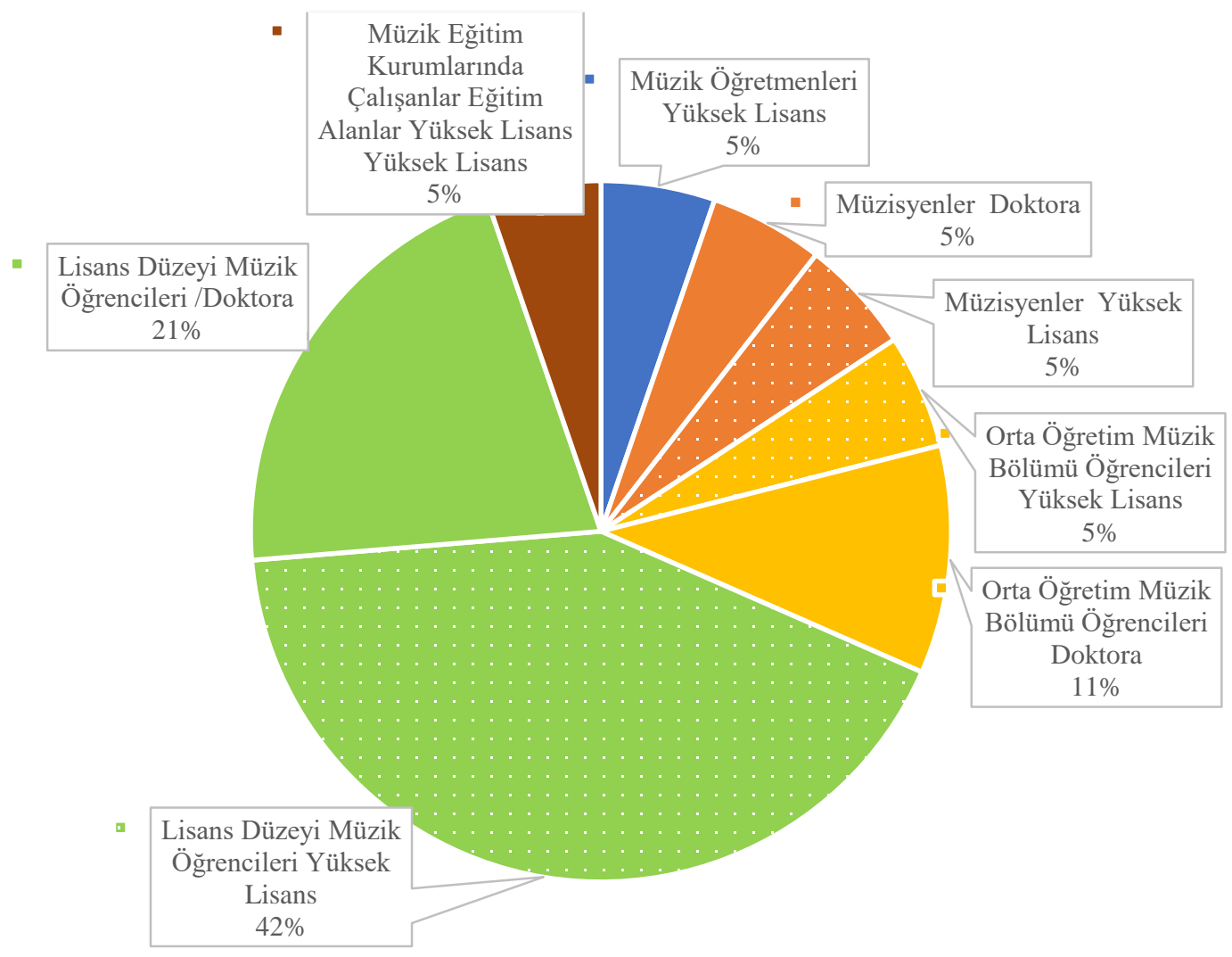

Şekil 1. Tezlerin Örneklem Grubuna Göre Dağılımı

Şekil 1'e bakıldığında doktora ve yüksek lisans tezlerinde en çok lisans düzeyi müzik öğrencileri ile çalışma yapıldığı görülmektedir. Bu örneklem grubu ile $\% 42$ oranla en çok yüksek lisans tezleri verilmiştir. Doktora programında ortaöğretim müzik bölümü öğrencileri araştırmada en çok çalışılan ikinci çalışma grubu olarak görülmektedir. 
Türkiye'de müzik performans kaygısı üzerine yazılan tezlerin kaynak özelliklerine göre dağılımı ile ilgili bulgular nasıldır?

Tablo 6: Türkiye'de Müzik Performans Kaygısı Üzerine Yazılan Tezlerin Kaynak Özellikleri

\begin{tabular}{lccccccc}
\hline & \multicolumn{2}{l}{$\begin{array}{l}\text { Türkçe kaynak/Türkiye } \\
\text { kaynaklı kaynak }\end{array}$} & $\begin{array}{l}\text { Yabanc1 } \\
\text { kaynak/Uluslararası } \\
\text { kaynaklı }\end{array}$ & Elektronik Kaynak & Toplam \\
\cline { 2 - 8 } Tez no & $\mathrm{F}$ & $\%$ & $\mathrm{f}$ & $\%$ & $\mathrm{f}$ & $\%$ & Toplam \\
\hline T.1. & 18 & 58.06 & 5 & 16.13 & 8 & 25.81 & 31 \\
T.2. & 43 & 72.88 & 15 & 25.42 & 1 & 1.70 & 59 \\
T.3. & 14 & 27.45 & 17 & 33.33 & 20 & 39.22 & 51 \\
T.4. & 25 & 62.5 & 11 & 27.5 & 4 & 10 & 40 \\
T.5. & 53 & 44.16 & 65 & 54.17 & 2 & 1.67 & 120 \\
T.6. & 34 & 11.53 & 258 & 87.45 & 3 & 1.02 & 295 \\
T.7. & 22 & 62.86 & 3 & 8.57 & 10 & 28.57 & 35 \\
T.8. & 64 & 58.72 & 45 & 41.28 & - & - & 109 \\
T.9. & 67 & 42.68 & 90 & 57.32 & - & - & 157 \\
T.10. & 47 & 33.10 & 93 & 65.49 & 2 & 1.41 & 142 \\
T.11. & 29 & 51.79 & 27 & 48.21 & - & - & 56 \\
T.12. & 77 & 54.23 & 65 & 45.77 & - & - & 142 \\
T.13. & 49 & 28.99 & 115 & 68.05 & 5 & 2.96 & 169 \\
T.14. & 29 & 13.00 & 189 & 84.75 & 5 & 2.25 & 223 \\
T.15. & 43 & 72.88 & 14 & 23.73 & 2 & 3.39 & 59 \\
T.16. & 31 & 36.91 & 46 & 54.76 & 7 & 8.33 & 84 \\
T.17. & 45 & 86.54 & 7 & 13.46 & - & - & 52 \\
T.18. & 23 & 15.97 & 117 & 81.25 & 4 & 2.78 & 144 \\
T.19. & 62 & 65.96 & 31 & 32.98 & 1 & 1.06 & 94 \\
\hline Genel Top. & 775 & 37,58 & 1213 & 58,83 & 74 & 3,59 & 2062 \\
\hline
\end{tabular}

Tabloya göre, incelenen tezler arasında en fazla 223 kaynakça kullanılmış ve bunun 189'u yabancı, 29'u Türkçe ve 5'i elektronik kaynaktan oluşmaktadır. Araştırmada en az 31 kaynaklı çalışma bulunmaktadır. Bu çalışmanın 18 Türkçe, 5 yabancı ve 8 elektronik kaynağı olduğu görülmektedir. Genel toplama bakıldığında, en çok yabancı kaynak sonra Türkçe kaynak en az ise elektronik kaynak kullanıldığı görülmektedir.

\section{Tartışma ve Öneriler}

Araştırmanın 1. alt amacına yönelik elde edilen bulgulara göre; tezlerin yıllara göre sayısal dağılımı verilmiştir. Sanatta yeterlik düzeyinde müzik performans kaygısına yönelik bir araştırmaya bulunmamıştır. Ayrıca 2006 yılına kadar yüksek lisans ve doktora tezi yapılmadığı araştırma sonucuna ulaşılmıştır. Müzik performans kaygısının literatüre yeni yeni kazanmaya başlandığı o yı1lar için söylenebilir. Kenny ve Osborne'un (2006) görüşlerine göre müzik performans kaygısı psikoloji alanında nadiren görülen ve nispeten ihmal edilmiş bir psikolojik fenomendir (Kenny ve Osborne, 2006). Müzik performans kaygisı psikoloji ile doğrudan ilişkili olduğundan bu konuda yapılan çalışmaların 2006 ve sonrasında gerçekleşmeye başladığı söylenebilir.

İlk periyot olan 2006-2010 y1lları arasında müzik performans kaygısı konusunu ele alan sadece yüksek lisans tezleri olduğu göze çarpmaktadır. Bir sonraki periyot 2011-2015'te ise doktora tezi kapsamında 2 çalışmanın yer aldığ görülmektedir. Doktora yapan araştırmacıların müzik performans kaygısı konusunda bu tarihler arasında ilgi duydukları sonucuna ulaşabiliriz. 2016-2020 yılları içerisinde tezlerin sayısında belirgin bir artış olduğu görülmektedir. Kenny (2004) müzisyenlerin performans kaygılarını belirleyebilmek amacıyla "Kenny Müzik Performans Kaygısı Envanterini”" (K-MPKE) geliştirmiş̧ir. K-MPKE, 2009 yılında tekrar revize edilmiştir (Kenny, 2009). Ülkemizde ise Banu Özevin Tokinan (2013) tarafından Kenny Müzik Performans Kaygıs1 
Envanteri Türkçe 'ye Uyarlama Çalışması literatüre kazandırılmıştır. 2016-2020 yılları arasında yapılan tezlerde bu envanter sıklıkla kullanıldığından bilimsel yayınlara önemli bir kaynak niteliği kazandırmış olduğu düşünülebilir.

Araştırmanın 2. alt amacına yönelik bulguların sonucunda; tablo 1'de müzik performans kaygısı üzerine yapılmış lisansüstü çalışmaların künyesi verilmiştir. Çalışmaların çoğunluğunun kadın araştırmacılar tarafından yapıldığı sonucuna ulaşılmıştır. Müzik performans kaygısı üzerine literatürde bulunan çalışmalara bakıldığında, performans kaygısını kadın müzisyenlerin daha fazla yaşadığı görüşü ağırlık kazandığı görülmektedir (Kenny ve Osborne, 2006; Thomas ve Nettelbeck, 2014). Elde edilen bu görüşe göre, müzik alanında çalışan kadın araştırmacıların bu konuya daha fazla ilgi duydukları söylenebilir.

Araştırmanın 3. alt amacına yönelik bulguların sonucunda; tezlerin üniversitelere göre sayısal dağılımı verilmiştir. Marmara Üniversitesi toplamda 5, Gazi Üniversitesi toplamda 3 ve İnönü Üniversitesi toplamda 2 tez vermiştir. Bu sonuca göre elde edilen tüm tezlerin yarısından fazlası bu üniverstelerde gerçekleşmiştir. Ayrıca elde edilen tezlerin yürütüldüğü enstitui ve programa bakıldığında, ilgili çalışmaların eğitim bilimleri enstitüsüne bağlı müzik öğretmenliği programlarında gerçekleştirildiği göze çarpmaktadır. Lisansüstü düzeyde müzik eğitimi veren Konservatuvar ve Güzel Sanatlar fakültesi müzik bölümlerinde müzik performans kaygısı konusunda gerçekleştirilen tezlerin az sayıda olduğu görülmektedir. Bu kurumlarda var olan programların yapısı gereği araştırmacıların bu konu alanına pek ilgi duymadıkları söylenebilir.

Araştırmanın 4. alt amacına yönelik elde edilen bulgulara göre; tezlerin konulara göre dağılımı yapılmıştır. Kaygı durum düzeylerinin belirlenmesinde çeşitli değişkenlerin ilişki ve etkisi \%69.29 oranla araştırma alanına en çok konu olan alandır. Son yıllarda performans kaygısını yordayabilecek kaygı ölçeklerinin geliştirilmiş olması bu konuda çalışmaların yoğunluk kazanmasına olanak sağlamış olabilir. Başa çıkma yöntem ve stratejileri konu alanında yapılan çalışmalar, tez konu alanının \%26.31'ini oluşturmaktadır. İlgili literatürde yapılan çalışmalar göz önünde bulundurulduğunda kaygı yaşamımızın bir parçasıdır ve kaygıdan kaçınmak mümkün değildir. Bu sebeple kaygı durumuna bütünüyle kapılmak veya kaçınmak yerine onunla baş edebilmenin üzerine durmak gerekir (Yıldırım, 1991). Psikoloji alanında son 40 yıldır kaygı ile başa çıkma teknikleri yaygın bir şekilde kullanılmıştır (Akbulut Bilici, 2020). Disiplinlerarası kavramı ayrı ayrı disiplinlerin zenginliğini, onların birbiriyle bağlantılı olduğunu, gerçek hayattaki problemlerin her zaman tek doğru cevabı olmadığını kabul etmekle birlikte konular içerisindeki ilişkiyi daha iyi ifade etmek ve yeni yollarını bulmak şeklinde tanımlanmaktadır (Çoruh, 2010). Bu bağlamda müzik performans kaygısı ile başa çıkabilme yöntemlerinin araştııılması psikoloji bilim dalı ile ilişkilendirmek mümkündür. Performans kaygısına neden olan faktörlere yönelik konu alanında yapılan çalışmalara bakıldığında ise tez konu alanın sadece \%5.26'sını oluşturmaktadır. Bu tür çalışmaların ortaya konması performansta yaşanan sorunların çözümü konusunda yol gösterici olabilir fakat bu konu alanında tasarlanan araştırmalarda müzik alanı dışında yer alan psikoloji gibi farklı disiplinlerin de çalışma kapsamına dahil edilmesine ihtiyaç duyulabilir. Bu nedenlerle araştırmacıların bu konu alanına ilgi durmadıkları söylenebilir.

Araştırmanın 5. alt amacına yönelik bulgularda; lisansüstü çalışmalar yöntemlerine göre incelenmiştir. Çalışmalarda kullanılan araştırma yöntemlerine bakıldığında ilişkisel tarama modeli ve betimsel model; tarama, deneysel, karma ve deneme modellerine göre daha çok tercih edilmiştir. Bu modellerin daha çok tercih edilmesindeki sebep Arık ve Türkmen'in (2009) araştırmalarında yer alan betimsel araştırmaların, deneysel araştırmalara göre daha az zaman almasından kaynaklanabilir. Araştırmalarda veri çözümlemesi olarak farklı teknikler kullanılmıştır. En çok kullanılan betimsel analiz ve betimsel istatistik olduğu saptanmıştır. Betimsel analiz, görüşme ve gözlem sonucu elde edilen verilerin düzenlenmiş ve yorumlanmış bir şekilde okuyucuya sunulmasıdır. Veriler daha önceden belirlenmiş temalara göre sinıflandırılır, özetlenir ve yorumlanır (Karataş, 2015: 73). 
Bunların yanısıra tarama, deneysel model, karma ve deneme modeli daha az kullanılmıştır. Yapılan araştırmada örneklem grubunun \%63'ü lisans bölümü müzik öğrencilerinden oluşmaktadır. Bu örneklem grubunun daha çok tercih edilmesindeki sebep ulaşılması diğer gruplara göre daha kolay ve sayıca fazla olmasından kaynaklanabilir. Çalışmalarda kullanılan veri toplama araçlarından daha çok kaygı ölçeği, bilgi formu ve anket kullanıldığı görülmektedir. Araştırma modellerinden betimsel araştırmaların daha fazla kullanıldığını da göz önünde bulundurduğumuzda veri toplama araçlarının bu yönde fazla olmasının birbirleri ile ilişkisi olduğu sonucuna varılabilir.

Araştırmanın 6. alt amacına yönelik bulgular sonucunda; incelenen tezlerde en fazla 223 kaynakça kullanılmıştır. Bu kaynakların 189'u yabanc1, 29'u Türkçe ve 5'i elektronik kaynaklardır. Araştırmada en az 31 kaynaklı çalışma bulunmaktadır. Araştırmada en fazla kaynak kullanılarak yapılan çalışma doktora tezidir. En az kaynak ise yüksek lisans tezinde kullanılmıştır. Doktora programları yüksek lisans programlarına göre bilimsel araştırmaları daha geniş ve derin bir bakış açısıyla sentezler. Araştırmanın sonucunda doktora tezinin en fazla kaynak sayısı kullanmasındaki sebep bu görüşü destekleyebilir. Genel toplama bakıldığında en fazla yabancı kaynak kullanıldığı görülmektedir. Akademik düzeyde gerçekleştirilen çalışmalarda kaynak kullanımında yabancı kaynak sayısının yeterli sayıda olması beklenir. Bu sonuca göre yabancı kaynak kullanım sayısının fazla olması dikkat çekici olmakla beraber Türkçe kaynak sayısının nispeten daha az oluşu da Müzik performans kaygısı konusunda yerli kaynakların sayısal açısından yetersiz oluşu göze çarpmaktadır.

Türkiye'de lisansüstü müzik performans kaygısı üzerine yapılmış çalışmalarda performans kaygısına neden olan faktörlere yönelik çalışma konusunun lisansüstü düzeyde yeteri kadar çalışılmadığ görülmüştür. Müzisyenlerin çoğunu etkilediği konusunda yaygın bir görüş olduğu düşünüldügünde, müzik performans kaygısı konusuna, alan araştırmacıların bu konuya daha fazla ilgi göstermeleri önerilmektedir. Bu çalışmalar müzik performans kaygısı ile ilgili çalışmaların araştırma konusu dağarcığını genişletebilir.

Müzik performans kaygısı neredeyse her öğrencinin belirli dönemlerde bile olsa hissettiği ve yaşadığı bir durumdur. Lisans düzeyi müzik eğitimi veren kurumlarda performans kaygisına yönelik derslerin olması hem kaygı ile baş etme konusunda öğrencilere fayda sağlayacak hem de lisansüstü düzeyde araştırmaların bu dersi alan öğrencilerden dolayı çalışmanın çeşitli konularda daha fazla araştırılabilir olmasını sağlayabilir.

Araştırma konusunda bibliyometrik çalışmalara yer verilebilir. Ayrıca müzik performans kaygısı ile başa çıkma stratejileri konusunun daha fazla çalışılması literatürü zenginleştirerek müzik öğrencilerine de katkı sağlayabilir.

\section{Kaynakça}

Adler, A. (1985). Insan tanıma sanatı. Say Kitap.

Akbulut Bilici, B. (2020). Flüt eğitiminde aşamalı kas gevşeme ezgersizlerinin öğrencilerin sınav kaygıları ve performans başarılarına etkisi. [Yayımlanmamış doktora tezi]. Gazi Üniversitesi Eğitim Bilimleri Enstitüsü.

Alkan, G. (2014). Türkiye'de muhasebe alanında yapılan lisansüstü tez çalışmaları üzerine bir araştırma (1984-2012). Muhasebe ve Finansman Dergisi, 61, 41-52.

Anonim. (2008). Anksiyete. Psykisk helse.

Arık, R. S., \& Türkmen, M. (2009). Eğitim bilimleri alaninda yayımlanan bilimsel dergilerde yer alan makalelerin incelenmesi. I. Uluslararası Türkiye Eğitim Araştırmaları Kongresi, Çanakkale Onsekiz Mart Üniversitesi. 
Başaran, M. H. (2008). Sporcularda durumluk ve sürekli kaygı düzeylerinin bazı değişkenlere göre incelenmesi. [Yayımlanmamış yüksek lisans tezi]. Selçuk Üniversitesi Sağlık Bilimleri Enstitüsü.

Baydağ, C., \& Bolat Başoğlu, M. (2018). Müzik eğitimi perspektifinde performans kaygısına genel bir bakış. Journal of Social and Humanities Sciences Research, 5(25), 2204-2212.

Büyüköztürk, Ş. (1997). Araştırmaya yönelik kaygı ölçeğinin geliştirilmesi. Kuram ve Uygulamada Ĕ̈itim Yönetimi Dergisi, 3(4), 453-464

Cemali, M. (2017). Müzik bölümü lisans ögrrencilerinde performans kaygısına neden olan faktörlerin belirlenmesi. [Yayımlanmamış yüksek lisans tezi]. Hacettepe Üniversitesi Sağlık Bilimleri Enstitüsü

Çankırıoğlu, S. (2007). Üniversite adayı ergenlerin stresle başa çıkma ve sınav kaygılarının bazı değişkenlere göre incelenmesi. [Yayımlanmamış yüksek lisans tezi]. Sakarya Üniversitesi Sosyal Bilimler Enstitüsü.

Çırakoğlu O. C. (2013). Sahnedeki düşman: müzisyenlerde performans kaygısı üzerine bir gözden geçirme. Türk Psikoloji Yazıları, 16(32), 95-104.

Çoruh, H. (2010). Disiplinlerarası bilim tarihi dersi ve gerekçesi. Journal of the History School, (7), $7-23$.

Dalkıran, E., Baltacı, H. Ş., Karataş, Z., \& Nacakcı, Z. (2014). Developing of indivudual instrument performance anxiety scale: validity-reliability study. International Journal of Assessment Tools in Educaton 1(1), 13-25. https://doi.org/10.21449/ijate.239569

Fehm, L., \& Schmidt, K. (2006). Performance anxiety in gifted adolescent musicians. Journal of Anxiety Disorders, 20(1), 98-109. https://doi.org/10.1016/j.janxdis.2004.11.011

Geçtan, E. (1997). Psikodinamik psikiyatri ve normal dışı davranışlar. Remzi Kitabevi.

Gencer, M. B. (2019). Müzik bölümü ögrencilerinde performans anksiyetesi, mükemmelliyetçilik ve başarı yönelimleri arasındaki ilişkinin incelenmesi. [Yayımlanmamıs yüksek lisans tezi]. Fatih Sultan Mehmet Vakıf Üniversitesi Lisansüstü Eğitim Enstitüsü.

Gidergi, A. (2012). Müzik performans anksiyetesi. Trakya Üniversitesi Sosyal Bilimler Dergisi, 14(1), 137-148.

Hökelekli, H. (2009). Psikolojiye giriş. Düşünce Kitabevi Yayınları.

Kabakçı, C. (2016). Sahne performans kaygısında farkındalık ve mücadele. Sahne ve Müzik Eğitim Araştırma e-Dergisi, 3, 86-96.

Karataş, Z. (2015). Sosyal bilimlerde nitel araştırma yöntemleri. Manevi Temelli Sosyal Hizmet Araştırmaları Dergisi. 1(1), 62-80.

Kenny, D. T. (2006). Music performance anxiety: origins, phenomenology, assesment and treatment. A Journal of Music Research, 31, 51-64.

Kenny, D., \& Osborne, M. (2006). Music performance anxiety: new insight from young musicians. Advances in cognitive psychology, 2(2-3), 103-112.

Kenny, D. T. (2009). The factor structure of the revised kenny music performance anxiety inventory. International Symposium on performance science, Auckland, New Zealand.

Koç, M. (2004). Gelişim psikolojisi açısından ergenlik dönemi ve genel özellikleri. Erciyes Üniversitesi Sosyal Bilimler Enstitüsü Dergisi, 1(17), 231-238. 
Kubal1, D. (1999). Performans denetimi. Amme İsaresi Dergisi, 32(1), 31-62.

Le Blanc, A., Jin, Y. C., Obert, M., \& Siivola, C. (2016). Effect of audience on music performance anxiety. JRME, 45(3), 480-496.

Levitin, D. J. (2015). Müziğin etkisindeki beyin. Pegasus Yayınc1lık.

McBurney M. K. \& Novak, P. L. (2002). What is bibliometrics and why should you care? IEEE International Professional Communication Conference, 108-114, 17-20 Eylül, Portland, Oregon, USA.

Özevin Tokinan, B. (2013). Kenny müzik performans kaygısı envanterini Türkçe'ye uyarlama çalışması. Ahi Evran Üniversitesi Kırşehir Ë̆itim Fakültesi Dergisi, 14(1), 53-65.

Öztürk, A. (2008). Manisa Celal Bayar üniversitesi beden eğitimi ve spor yüksekokulu öğretmenlik programı ögrencilerinin durumluk ve sürekli kaygı düzeyleri ile akademik başarıları arasındaki ilişki. [Yayımlanmamış yüksek lisans tezi]. Manisa Celal Bayar Üniversitesi Sağlık Bilimleri Enstitüsü.

Pişkin, M. (1991). Empati, kaygı ve çatışma eğillimi arasındaki ilişki. Ankara Üniversitesi Eğitim Bilimleri Fakültesi Dergisi, 22(2), 775-784.

Pritchard, A. (1969). Statistical bibliography or bibliometrics? Journal of Documentation, 25, 348349.

Say, A. (2008). Müzik nedir, nasıl bir sanattır? Evrensel Basım Yayın.

Sarıkaya, M. (2018). Müzik öğretmeni adaylarının mükemmelliyetçilik ve öz-yeterlik inançlarına göre müzik performans kaygılarının yordanması. [Yayımlanmamış doktora tezi]. Necmettin Erbakan Üniversitesi Güzel Sanatlar Eğitimi Anabilim Dalı.

Türk Dil Kurumu [TDK]. (2020). İnsan tanımı, 27 Nisan 2020 tarihinde https://sozluk.gov.tr/ adresinden erişildi.

Türk Dil Kurumu [TDK]. (2020). Performans tanım1, 12 Mayıs 2020 tarihinde https://sozluk.gov.tr/ adresinden erişildi.

Thomas, J. P., \& Nettelbeck, T. (2014). Performance anxiety in adolescent musicians. Psychology of Music, 42(4), 624-634.

Türkçapar, H. (2004). Anksiyete bozukluğu ve depresyonun tanısal ilişkisi. Klinik Psikiyatri, 4, $12-$ 16.

Uluç, M. Ö. (2013). Müzik cep sözlüğ̈̈. Müzik Eğitimi Yayınları.

Yıldırım. İ. (1991). Stres ve stresle başa çıkmada gevşeme teknikleri. Hacattepe Üniversitesi Eğitim Fakültesi Dergisi, (6), 175-189

Yöndem, Z. (2012). Müzik öğrencilerinde algılanan performans kaygısının fiziksel, davranışsal ve bilişsel özellikleri: nitel bir çalışma. Ĕgitim ve Bilim, 37(166), 181-194. 